\title{
Analysis of Political Broadcasting and Application Of P3SPS Broadcasting In Local Television and Network Station Systems an Makassar City
}

\author{
Andi Muh. Fadli ${ }^{1}$, Risma Niswaty ${ }^{2}$ \\ ${ }^{1}$ Universitas Islam Negeri Alauddin Makassar \\ ${ }^{2}$ Universitas Negeri Makassar \\ E-mail: ${ }^{1}$ Andimuhfadli75@gmail.com, ${ }^{2}$ risma.niswaty@unm.ac.id
}

\begin{abstract}
In mass communication, one of the most influential media in forming public opinion is television. This study aims to determine and analyze: the form of political broadcasts on local television and network station systems in Makassar City; and the application of P3SPS in political broadcasts on local television and network systems in Makassar City. The assessment approach uses media studies, research studies focus more on the phenomenon of online media with a focus on the application of values and ethics of journalists, also related to the process of making news, disseminating news and performance, access to news and practice in dismissing hoax news. Informants involved in this study, such as: Television Media workers in Makassar City; Experts or Media Practitioners in Makassar City; and government authorities such as the KPID of Makassar City. The form of political broadcasts on local television and the network station system in Makassar City consists of three, namely political news, political dialogue and political advertising. The application of P3SPS in political broadcasts on local television and network systems in Makassar City is carried out according to procedure. During the open campaign process in broadcasting, there were violations that were violated by broadcasters.
\end{abstract}

Keywords: politically charged broadcasts, Broadcast Code of Conduct and Program Standards, online media, journalistic values and ethics

\section{INTRODUCTION}

Since the beginning of the presence and development of media in western countries, it has been seen as one of the most effective tools for developing public discourse and opinion. Therefore, the media has a role in various arenas of public life, including in the political aspect. One of the roles of the media is to disseminate political influence and shape public opinion that is scheduled by political actors.

From the development of the media and its potential to shape and influence public opinion, experts then refer to the media as a fourth force in the context of social, economic and political life (Niswaty \& Arhas, 2019; Suprianto, Arhas, \& Salam, 2018). Even mentioned as the fourth pillar of democracy. Because the media has a strong role in controlling power in a country.

In mass communication, one of the most influential media in forming public opinion is television. Hermin Indah Wahyuni said that like other mass media, television was born as an entity rooted in its social environment. Television is a business entity, social entity, cultural entity, as well as a political entity (Sandoval Forero, 2002; Solihat, 2008; Wulandari, 2017)

Copyright @ 2019 Universitas Negeri Makassar. This is an open access article under the CC BY license (http://creativecommons.org/licenses/by/4.0/) 


\author{
116 Jurnal Administrare: Jurnal Pemikiran Ilmiah dan Pendidikan Administrasi Perkantoran \\ Volume 6 Number 2 July- December 2019. Pages 115-122
}

Until now, television was considered to still have a large role in disseminating these political interests. In the Indonesian context, for example, various ways are used by political actors to include their political agenda in the transformation of mass media information such as television (Hollander, D'Haenens, \& Bardoel, 2009; Taqwa, 2009) . Including by influencing the ownership of the media itself. However, this influence can be anticipated by the enactment of various regulations and guidelines in the information dissemination system. Like the validity of the code of conduct and behavior for television media actors in the process of producing information which is ultimately consumed by the public.

A media attains temporary objectivity in the newsroom various interests intervening in the news production process. The appearance of the media becomes a projection of the power of the dominant ideology that controls the media (Choo, 2011; Newton, 1999; Salam, Zunaira, \& Niswaty, 2016; Saleh, Arhas, Haerul, \& Nasaruddin, 2019). Factuality is associated with the form of presentation of reports about events or statements that can be checked for truth at the source and without comment. Impartiality is associated with attitudes that distract personal and subjective judgment in achieving desired goals. Factuality is determined by truth criteria, among others; integrity of the report, the accuracy of which is supported by a person's consideration of an information, regardless of the importance of the contents of the information. Denis, (in Sudibiyo, 2001: 47) argues, objectivity can be achieved in three ways: Separation between facts and opinions, presenting news without emotional situations, being honest and balanced towards all parties.

\title{
METHOD
}

This research uses a qualitative methodology. The scope of research is on television and networked stations in Makassar City. The location determination is based on observations related to the presence of television media that are actively providing news in the Makassar city community. The time was carried out in June-August in 2019. The Research Approach was understood in two perspectives, first the assessment approach used the study of media studies, the research study focused more on the phenomenon of online media with a focus on the application of values and ethics of journalists, related also to the process of making news, disseminating news and performance, access to reporting and practice in political news and the application of behavioral guidelines and broadcast program standards for Makassar network and local television stations.

\section{RESULT AND DISCUSSION}

In order to determine the effect of compensation on employee work performance in the The magnitude of the influence of the tv media places it in a strategic position not only in the dissemination of information in general, but also in political messages or in the interests of power to influence public political views and choices. Utilization of the influence of TV media is especially carried out by political actors who have strong relations and capital to the ownership of the TV media industry. As seen or witnessed publicly during the 2019 presidential and vice presidential elections. Not only national TV, local stations and networks that operate in the provincial capital cannot be separated from the influence of local politics. Although the 
level of percentage cannot be stated in more detail, the indication can be seen from the framing of local broadcast content.

\section{Forms Of Political Broadcasts On Local Television And Network Station Systems In Makassar City}

TV broadcasting is formally regulated in Act No. 32 of 2002 concerning Broadcasting. Specifically in article 13, which explains broadcasting services. Based on data from the Communication, Information, Statistics and Statistics Office of South Sulawesi, the number of local television stations that broadcast actively in Makassar City is 3 stations, namely TVRI Sulsel, Celebes TV and Fajar TV. Previously, there were local stations that tried to broadcast, namely Ve Channel and GO TV which used Sakti TV. In addition, there are also network tv stations such as NET TV Sulsel, TV One Bureau, Trans TV and Trans 7, MNC group inews group and Kompas TV Bureau.

Each bureau broadcasts local broadcasts at least 20 percent of all broadcast hours. One of the local networks that is not in the form of a bureau is Net TV Sulsel. This television uses channel 57 which is broadcasted through stations in Takalar Regency. The obligation of each national TV network to local networks also requires the media to broadcast local information that can be watched by the public in parts of South Sulawesi. To be able to broadcast Net Sulsel using the local TV station network of Horizon Adyswara Media.

From the data of the South Sulawesi Communication and Information Agency, the number of companies or local TV broadcasting institutions that submitted the licensing process to the South Sulawesi Regional Broadcasting Commission (KPID) in 2017 is actually far more than the number that currently exists in broadcasting. The number reached 30 institutions, most of which received recommendations and permits. A total of 12 of them are domiciled in Makassar City while others are scattered in other areas.

The main obstacle faced by local TV broadcasts is a small source of advertising revenue. Advertisers from the private sector generally choose to advertise through national TV broadcasts in Jakarta because of the wider broadcast coverage. Some local TV broadcast managers complain about regulations that do not regulate the private sector so that they advertise according to the broadcast area.

The framing of information in the news is strongly influenced by factors which by Shoemaker and Reese (1996) are divided as follows: individual level. The characteristics of communicators - in this case individual media workers - such as gender, ethnicity, and personal experience, not only shape their attitudes, values and beliefs, but also shape their professional ethics and roles; Media Routine Levels, routine is defined as all activities that are repeated and patterned at work. Media routines function so that the media responds in a way that is predictable and not easily violated. This routine forms a set of rules and becomes an integral part of the work of media professionals; Organizational Level, media organization is defined as a formal social and economic entity that employs media practitioners to produce media content; Extra Media Levels, these are factors outside the media organization that can influence media content, such as information sources (interest groups, etc.), sources of profit (advertisers, audience), other social institutions (business and government institutions), and the economic environment and technology; Ideological Levels, ideology is a symbolic mechanism that functions as a cohesive and integrative force in society. As a relatively formal and articulated 
118 Jurnal Administrare: Jurnal Pemikiran Ilmiah dan Pendidikan Administrasi Perkantoran Volume 6 Number 2 July- December 2019. Pages 115-122

system of meanings, values and beliefs, ideology functions as the way people view the world. But on local TV political broadcasts during the regional elections (Pilkada), the third and fourth factors were the most influential elements. Local broadcasters really use political momentum to benefit economically by framing. This effort aims to improve the image of politicians who participated in the elections, even used to disseminate political information that can reduce the popularity of political opponents (negative and black campaign).

In the election of the Mayor of Makassar in 2018 for example, framing politicians in political news was very easily identified on local television broadcasts in Makassar. One of them was on the Celebes TV news broadcast. This broadcasting institution is one of the local television media that owns the highest percentage of news broadcasts and talk shows in Makassar. Therefore often referred to as the first local news TV in Makassar. This broadcast media is also the only local TV that airs for 15 hours with own production program and fully involving local resources. Its ownership is also purely controlled by local entrepreneurs, namely the Aksa Mahmud family, the businessman who founded the well-known company, Bosowa Corporation.

In the context of realizing a democratic post-conflict local election, political broadcasts through mass media such as television have been regulated in the regulations of the General Election Commission (KPU). (Peraturan Komisi Pemilihan Umum 2009), explains that reporting, broadcasting and campaign advertising is the delivery of campaign messages by a candidate pair to the public through printed and electronic media repeatedly in the form of writing, pictures, animations, promotions, sounds, demonstrations, plays, debates, and other forms that contain invitations, appeals to provide support to candidate pairs.

The regulation also explained the form of the campaign which included the dissemination of political messages through television broadcasts as part of it. Specifically the form of campaign referred to in the General Election Commission is as follows: limited meetings; face to face and dialogue; dissemination through print and electronic media; broadcast via radio and / or television; disseminating campaign materials to the public; installation of props in public places; general meeting; public debate / open debate between candidates; and / or; other activities that do not violate the laws and regulations, including declaration or convention of candidate pairs by political parties or a combination of political parties, birthday / milad events, social and cultural activities, sports competitions, istighosah, leisure walks, grand tabligh, arts and bazaars and general meetings.

The issuance of KPU regulations which helped define political broadcasts through television and radio as a campaign message practically dragged the KPUD to be involved in efforts to create justice in the use of broadcast media for political purposes. Therefore, in addition to exercising its authority on a regular basis in overseeing broadcasting, the KPID has the duty and responsibility in creating direct, general, free, confidential, honest and fair elections. In carrying out this task, KPID stands on the rules stipulated in the Broadcasting Law No. 32/2002, Law 33/2009 concerning Film and KPU regulations. Based on these state products, the KPID focuses monitoring of political broadcasts related to the General Election and the Regional Head Election on the following aspects: legality or licensing; neutrality, fair and balanced; advertising (percentage, duration, frequency); public service announcements (non-partisans) to increase political participation \& solicitation for post-conflict local elections; blocking time; sensor pass mark; content (messages and visualizations); time / broadcast hour; child exploitation; quick count; errata; archive broadcast 
2018 became a gamble on the image of Celebes TV as a local broadcasting institution which has three big missions as expressed in the first part of this research. Celebes TV has also been known as an independent local broadcasting institution and upholds balance in every presentation of its information. However, his position as a broadcasting institution required by the law to be a social and political glue was tested by the advancement of one of the members of the tv-owned family in the election of the mayor of Makassar. Munafri Arifuddin, son-in-law of Aksa Mahmud, registered through a number of political parties to fight the candidate who was serving as Mayor of Makassar at the time, Muhammad Ramadhan Pumanto (Dani).

Munafri paired up with South Sulawesi Nasdem Party politician Andi Rahmatika Dewi or familiarly called Cicu. The election of the mayor of Makassar in 2018, which involved them, was full of conflict. During the campaign and election period, these politicians used a strategy of all means aimed at killing the character of political opponents. Including the use of tv in the form of news framing that can be analyzed from the news since 2017. Exactly when the candidate begins to socialize and register as an official participant through political parties or through individual candidates to the organizer or the Regional Election Commission of South Sulawesi.

For a mass media politician, it can be categorized as a political resource that can be utilized as much as possible to support political victory. This is as explained in the previous section, because television media has a wide reach and is one of the effective means of disseminating information in the public domain. Therefore, in many political events, television media are always used to improve the political image of actors or political elites. At the national level too, the indications can be seen

from the development of mass media ownership, including television controlled by businessmen as well as politicians. In the context of the 2018 Makassar mayor election, Celebes TV can also be categorized as capital owned by Munafri's political camp as one of the candidates in the election because it is part of the owner. Moreover, as a newcomer to the political stage, his popularity was still far below that of a Dani who had served as the mayor of Makassar before.

This can be seen from the hard work of Munafri's political camp which from the beginning controlled the political party's door so that Dani could not run for office. However, because Dani's political electability in 2017 to 2018 was very high, especially with the support of the bureaucratic network in Makassar City because he served as mayor of Makassar he still had opportunities through individual channels. In various surveys, Dani Pumanto's position is always in the top position to beat other candidates.

Based on the results of the monitoring of South Sulawesi KPID, Celebes TV broadcasts during the 2018 Pilwalkot process had an influence on the mapping of local television political broadcasts and network stations in Makassar City. As can be seen in table 2. Mapping conducted by KPID lasted from February to June against 6 TV stations (Table 1). The news about Munafri reached 382 with positive prominence while Dani only 67 news, and on the contrary Dani who then partnered with Indira Mulyasari had negative news, as many as 206 news, while Munafri only 27 news. 
120 Jurnal Administrare: Jurnal Pemikiran Ilmiah dan Pendidikan Administrasi Perkantoran

Volume 6 Number 2 July- December 2019. Pages 115-122

Tabel 1. Mapping of Makassar's Mayor Election News \& 2018 South Sulawesi Regional Election

\begin{tabular}{lrcc}
\hline & Positive & Negative & Neutral \\
\hline Dani Pomanto / & 67 & 206 & \\
Empty Box & 382 & 27 & \\
Munafri Arifuddin & 44 & 0 & \\
Nurdin Halid & 17 & 0 & 899 \\
Agus Arifin & 26 & 0 & \\
Nu'mang & 33 & 18 & \\
Nurdin Abdullah & & & \\
Ichsan Yasin Limpo & &
\end{tabular}

According to South Sulawesi KPID member, Herwanita, from the 6 TV stations that were the object of KPID monitoring, Celebes TV was the largest broadcasting contributor to Munafr positive news and Dani negative news.

This does not only happen at Celebes TV, a number of other TV stations also do the same thing. Most do not pay attention to the principles of balance, including in the selection of disproportionate sources. At the 2018 Pilwalkot Makassar, local TV stations even seemed to show positions opposite from the side of the news prominence. Local media in this case became an arena for political discourse to raise the image of their respective heroes. See table 4 for the selection of speakers at the local Fajar TV station. During February the KPID data showed that there were more informants from DIAmi's political camp and his campaign team than the AppiCicu camp. Far back compared to the Celebes TV news broadcast.

Table 2. TV News in South Sulawesi Regional Election and Makassar Regional Election, February 2018

\begin{tabular}{clrc}
\hline No & \multicolumn{1}{c}{ TV Station/ Candidate } & Positive & Negative \\
\hline $\mathbf{1}$ & Celebes TV & & \\
& - DIAMI & 2 & 89 \\
& - APPI-CICU & 134 & 2 \\
$\mathbf{2}$ & Fajar TV & 14 & 6 \\
& - Dani Pomanto & 4 & 8 \\
& - Munafri & & \\
$\mathbf{3}$ & Inews & 10 & 1 \\
& - Dani Pomanto & & \\
& - Munafri & 2 & 3
\end{tabular}




\begin{tabular}{|c|c|c|c|}
\hline No & TV Station/ Candidate & Positive & Negative \\
\hline \multirow{3}{*}{4} & TVRI & & \\
\hline & - Dani Pomanto & 0 & 0 \\
\hline & - Munafri & 0 & 0 \\
\hline \multirow[t]{3}{*}{5} & Ve Channel & & \\
\hline & - Dani Pomanto & 1 & 3 \\
\hline & - Munafri & 3 & 0 \\
\hline \multirow[t]{3}{*}{6} & Metro TV & & \\
\hline & - Dani Pomanto & 0 & 0 \\
\hline & - Munafri & 1 & 0 \\
\hline
\end{tabular}

\section{CONCLUSION}

The form of political broadcasts on local television and the network station system in Makassar City consists of three, namely political news, political dialogue and political advertising. The frequency of coverage in the Makassar mayor election was dominated by Munafri Arifuddin and Rahmatika Dewi (Appi-Cicu) in a positive tone. This is inversely proportional to the Dani Pomanto - Indira Mulyasari (DIAMI) couple who received a large amount of negative tones. The main issue that made the DIAMI couple's negative tone large was the issue of abuse of power by candidate Dani Pomanto who was also the incumbent of the mayor of Makassar. In dialogue, the frequency of broadcasting in the Makassar mayor election tends to be neutral, although in some topics DIAMI candidate pairs (before being disqualified) get more negative notes. Then the advertisements, distribution during the open campaign and the campaign period in the mass media, especially television in the Makassar Mayor election contest in 2018 were dominated by candidate pairs Munafri Arifuddin and Rahmatika Dewi (Appi-Cicu) this was due to the death of the Dani Pomanto-Indira Mulyasari (DIAMI) contestants who became the the sole opponent of the Appi- Cicu pair due to abuse of authority when they were the Mayor of Makassar.

The application of P3SPS in political broadcasts on local television and network systems in Makassar City is carried out according to procedure. During the open campaign process in broadcasting institutions in South Sulawesi, there were violations that were violated by broadcasters. Among them is the issue of imbalance in broadcasting institutions which violates Article 71 of SPS Point 2 regarding "Broadcasting programs must be fair and proportionate to participants in the General Election and / or Regional Head Elections". But South Sulawesi KPID puts forward a persuasion approach to broadcasters, and applies sanctions to the extent of a written warning. 
122 Jurnal Administrare: Jurnal Pemikiran Ilmiah dan Pendidikan Administrasi Perkantoran
Volume 6 Number 2 July- December 2019. Pages 115-122

\section{REFERENCES}

Choo, K. (2011). Television \& New Media. Television \& New Media. https://doi.org/10.1177/1527476411418255

Hollander, E., D’Haenens, L., \& Bardoel, J. (2009). Television performance in Indonesia 2006 steering between politics, civil society, and market. Asian Journal of Communication.

Newton, K. (1999). Mass media effects: Mobilization or media malaise? British Journal of Political Science. https://doi.org/10.1017/S0007123499000289

Niswaty, R., \& Arhas, S. H. (2019). The Effect of Learning Media on Progress Quality in Office Administration Program in Vocational School Negeri 1 Watampone Bone Regency. Journal of Physics: Conference Series, 1387. https://doi.org/10.1088/1742$6596 / 1387 / 1 / 012042$

Peraturan Komisi Pemilihan Umum 2009. Peraturan Komisi Pemilihan Umum 2009. , KPU § (2009).

Salam, R., Zunaira, Z., \& Niswaty, R. (2016). Meningkatkan Hasil Belajar Membuat Dokumen melalui Penggunaan Model Pembelajaran Kooperatif Tipe Make a Match (Mencari Pasangan). Jurnal Office, 2(2), 173-180.

Saleh, S., Arhas, S. H., Haerul, H., \& Nasaruddin, N. (2019). Utilization of Learning Media in Digital Simulation Subjects. Jurnal Office, 4(2), 79-90.

Sandoval Forero, E. A. (2002). Television y política mediatica en Mexico. Revista de Ciencias Sociales.

Solihat, M. (2008). Komunikasi Massa dan Sosialisasi. Mediator: Jurnal Komunikasi. https://doi.org/10.29313/mediator.v9i1.1143

Suprianto, S., Arhas, S. H., \& Salam, R. (2018). Pengaruh Media Pembelajaran dan Pengelolaan Kelas terhadap Prestasi Belajar Siswa di SMK Negeri Kecamatan Tanete Riattang, Kabupaten Bone. Jurnal Ad'ministrare, 5(2), 137-146.

Taqwa, R. (2009). Relasi Kuasa Anatara Media Televisi yang Dominatif-Hegemonik vs Audiens Aktif-Kritis. Jurnal Wacana Indonesia Vol. 1 No. 1 Desember 2009.pdf.

Wulandari, N. A. D. (2017). Lembaga Penyiaran Publik Indonesia dalam Persimpangan Idealisme Vs Ekonomi Politik Media. Interaksi: Jurnal Ilmu Komunikasi. https://doi.org/10.14710/interaksi.5.1.78-89 